\title{
GAYA BAHASA PERBANDINGAN DALAM NOVEL CATATAN JUANG KARYA FIERSA BESARI: KAJIAN STILISTIKA DAN RELEVANSINYA SEBAGAI BAHAN AJAR SASTRA DI SMA
}

\author{
Ariyani Dwi Andhini ${ }^{1}$, Zainal Arifin ${ }^{2}$ \\ 1,Pendidikan Bahasa dan Sastra Indonesia \\ Universitas Muhammadiyah Surakarta \\ 1ariyanidwiandhinipbi@gmail.com \\ 2,Pendidikan Bahasa dan Sastra Indonesia \\ Universitas Muhammadiyah Surakarta \\ 2za135@ums.ac.id ${ }^{2}$
}

\begin{abstract}
Abstrak
Penelitian yang dilakukan bertujuan untuk mendiskripsikan gaya bahasa yang terdapat dalam novel Catatan Juang karya Fiersa Besari, serta relevansinya sebagai bahan ajar sastra di SMA. Penggunaan gaya bahasa yang digunakan dalam novel Catatan Juang yaitu gaya bahasa perbandingan karena penulis banyak menggunaakan gaya bahasa perbandingan. Objek dalam penelitian ini adalah kalimat yang memiliki gaya bahasa perbandingan, sedangkan subjek penelitian adalah novel yang berjudul Catatan Juang karya Fiersa Besari. Teknik pengumpulan data yang digunakan adalah teknik pustaka, teknik simak, dan teknik catat yang digunakan untuk mempermudah mengumpulkan data yang berupa kalimat yang memilki gaya bahasa perbandingan. Hasil penelitian yang telah dilakukan adalah ditemukan 121 gaya bahasa yang terdiri dari gaya bahasa hiperbola berjumlah 45, metanomia 5, personifikasi 20, perumpamaan 35, pleonasme 5, metafora 3, simile 3, asosiasi 3, dan hipalase 5. Hasil penelitian yang telah dilakukan memiliki kelayakan sebagai bahan ajar sastra di SMA yaitu dalam segi bahasa, psikologi, dan latar belakang. Serta mampu diterapkan dalam KD 3.9.
\end{abstract}

Kata kunci: gaya, bahasa, dan perbandingan.

This study aims to describe the language style used in the novel Juang Notes by Fiersa Besari, and its relevance as a literature teaching material in high school. The use of the abhasa style used in this novel is the comparative language style because the author uses a lot of comparative language styles. The object in this study is a sentence that has a comparative language style, while the research subject is a novel entitled Notes Juang by Fiersa Besari. The data collection techniques used were library techniques, listening techniques, and note-taking techniques used to collect data in the form of language styles. The results of the research that have been carried out are found 121 language styles consisting of 45 hyperbolic language styles, 5 methanomia, 20 personifications, 35 parables, pleonasm 5, metaphor 3, simile 3, association 3, and hipalase 5. The results of the research that have been conducted have eligibility as a literature teaching material in high school, namely in terms of language, psychology, and background. And can be applied in KD 3.9.

Keywords: comparisons, styles and languages 


\section{PENDAHULUAN}

Karya sastra adalah bentuk yang dapat menghasilkan suatu pekerjaan yang kreatif dan inovatif dari seorang sastrawan, pada dasarnya karya sastra adalah suatu wadah yang dapat merealisasikan bahasa untuk mengungkapkan kehidupan yang dituangkan dalam suatu karya (Raharjo,2017). Menurut Suryani (2010) karya sastra muncul sebagai hasil perenungan pengarang terhadap sebuah fenomena kehidupan para pengarang sehingga karya yang diciptakan bukan ganya sekedar khayalan pengarang saja, melainkan cerita hidup atau cerita sehari - hari para pengarang yang dituangkan dalam sebuah kreativitas sastra yang unik. Hasil dari sebuah kreativitas para pengarang yaitu sebuah karya sastra tidak terlepas hari penggunaan bahasa sebagai sarana dalam menuangkan sebuah karya sastra. Bahasa dan kehidupan manusia sangat memiliki hubungan yang erat karena kedua hal tersebut memiliki keberaadn yang sangat penting dalam menjalani kehidupan bersosial. Keberadaan sebuah karya sastra erat hubungannya dengan permasalahan yang ada pada manusia dan permasalahan dengan lingkungannya, dari hal tersebut kemudian dikembangkan oleh para sastrawan menjadi sebuah karya sastra yang memiliki keunikan tersendiri. (Ibrahim, 2015).

Karya sastra menjadi ekspresi kejadian, pandangan, gagasan, dan nilai kehidupan yang diamanatkan melalui karya tersebut, dan sebuah karya sastra juga memiliki manfaat sebagai bekal, bahan, atau materi untuk memahami, mendapatkan, atau menggali informasi tentang manusia dan kondisi budayanya selama waktu tertentu (Sunanda, 2020). Karya sastra menampilkan sebuah permainan kata yang memiliki keunikan atau ciri khas tertentu kemudian disampikankan kepada para pembaca atau penikmat sastra. Sebuah karya sastra yang diciptakan oleh sastrawan dijadikan bentuk luapan perasaan pengarang yang berbentuk tulisan yang dirangkai menggunakan bahasa yang unik dan memiliki ciri khas tersendiri. Karya sastra yang memiliki ciri khas tertentu maka sebuah karya yang diciptakan menggunakan bahasa yang baik dan memanfaatkan segala gaya bahasa yang ada (Sudjiman, 1993).

Jenis karya sastra yang zaman sekarang sedang digemari anak muda adalah novel. Novel merupakan salah satu karya sastra fiksi yang menawarkan sebuah isi atau alur cerita yang imajinatif serta memiliki hubungan dengan perjalanan hidup seorang pengarang yang dituangkan dalam bentuk karya sastra fiksi yang memiliki ciri khas sesaui dengan karakter masing-masing pengarang. Suatu novel menyajikan sebuah tempat atau ruang yang memiliki hubungan tentang keberadaan ruang dan tempat manusia, sehingga mengakibatkan novel yang ditulis oleh beberapa pengarang berhubungan kehidupan masing-masing pengarang dan dijadikan sebagai topik utama dalam penulisannya (Sayuti, 1997). Novel juga memiliki hubungan yang sangat erat dengan kehidupan para pengarang, sehingga dalam setiap novel memiliki nilai-nilai yang dapat dijadikan suatu pelajaran yang dapat diambil oleh para pembaca atau penikmat sastra (Khusnin, 2012).

Media yang digunakan dalam penulisan novel adalah bahasa (Susilowati, 2016). Bahasa dijadikan sebagai sarana dalam penyampaian sebuah karya sastra novel, sehingga novel yang memiliki bahasa yang unik atau gaya bahasa yang beragam akan diminati oleh para pembaca. Salah satu karya sastra novel yang banyak di gemari anak muda pada zaman sekarang adalah karya dari Fiersa Besari. Fiersa Besari adalah penulis sekaligus penyanyi dan menghasilkan eman novel, salah satu novel yang di gemari oleh anak muda adalah novel yang berjudul Catatan Juang. Novel ini Catatan Juang menceritakan tentang perjalanan hidup 
seorang perempuan yang berjuang menjadi seseorang yang sukses, jadi novel ini cocok digubakan sebagai bahan ajar di SMA.

Gaya bahasa yang digunakan dalam novel merupakan wujud penggunaan bahasa oleh peangarang atau penulis dalam untuk menuangkan gagasan, pendapat yang dapat dinikmati oleh para pembaca (Aminuddin, 1997). Selain penggunaan gaya bahasa unsur lain yang juga penting adalah pilihan kata atau diksi. Pemilihan kata atau diksi memiliki peran yang sangat penting karena menyangkut tentang pilihan kata yang tepat dengan isi novel sehingga harus sesuai dengan isi novel. Sehingga gaya bahasa dan diksi memiliki hubungan dalam penciptaan suatu karya sasta novel (Wibowo, 2001).

Menurut Faricha, (2015) gaya bahasa memiliki keterkaitan dengan diksi atau pilihan kata karean berkaitan dengan suatu ungkapan yang berkaitan dengan karakteristik yang khas dari para pengarang. Aminuddin (2011) juga berpendapat bahwa gaya bahasa dijadikan cara pengarang untuk menyampaiakn suatu gagasan atau karangan dengan memanfaatkan media yang indah dan mampu memuaskan makna san suasan para pembaca.

Dalam mengkaji sebuah penggunaan gaya bahasa kajian yang tepat adalah Kajian stilistika. Pendekatan yang digunakan dalam kajian stilistika adalah pendekatan obyektif. Penggunaan kajian stilistika dalam penelitian ini bertujuan untuk mempermudah peneliti dalam memahami suatu gaya bahasa yang digunakan serta mampu menikmati gaya bahasa yang digunakan dalam menyampikan isi atau alur cerita dalam novel Catatan Juang. Penggunaan kajian stilistika diharapkan mampu memperoleh hasil yang telah direncanakan mampu mempenuhi kriterio obyektivitas yang telah ditetapkan sebelumya (Aminuddin, 1995). Penggunaan gaya bahasa yang ada dalam novel yang berjudul Catatan Juang sangat menarik unutk dilakukan karena penulis banyak menggunaan gaya bahasa perbandingan untuk menyampaiakan isi dalam novel.

\section{METODE PENELITIAN}

Penelitian yang berjudul "Penggunaan Gaya Bahasa Perbandingan dalam Novel Catatan Juang Karya Fiersa Besari: Pendekatan Stilistika dan Relevansinya sebagai Bahan Ajar Sastra SMA" menggunakan pendekatan kualitatif. Metode penelitian kualitatif adalah penelitian yang mempunyai prosedur berupa kata - kata tertulis dan lisan dalam menghasilkan data yang bersifat deskriptif (Moleong, 2000). Data kualitatif adalah data penelitian yang berkaitan dengan kuantitas (Sutopo, 2006). Data penelitian ini adalah berupa data tertulis yang berupa kalimat dari novel Catatan Juang karya Fiersa Besari yang menggunakan gaya bahasa tetentu. Selain itu data dalam penelitian ini adalah unsr pembangun novel yang berupa tema, alur, penokohan, dan amanat, serta kalimat atau paragraf yang menunjukkan kelayakan sebagai bahan ajar sastra SMA. Sumber data adalah sumber memperoleh data, sember data dapat berupa teks dan buku yang berkaitan dengan objek yang diteliti (Siswanto, 2010). Sumber data yang akan digunakan dalam penelitian ini adalah novel yang berjudul Catatan Juang karya Fiersa Besari. Teknik pengumpulan data yang diguanakan dalam penelitian ini adalah studi pustaka, sinak, dan catat sebagai pengumpulan data. Teknik pustaka, dilakukan untuk mancari dan mengumpulkan informasi dari sumber data dokumen tertulis yaitu novel Catatan Juang. Teknik ini digunakan untuk mencari referensi tentang gaya bahasa yang digunakan dalam novel yang berjudul Catatan Juang. Teknik simak, dilakukan dengan membaca, mencermati, dan memahami untuk memperoleh data berupa penggunaan gaya bahasa dan relevansinya sebagai bahan 
ajar sastra SMA. Teknik catat, dilakukan peneliti setelah membaca sumber data untuk mencatat hasil - hasil dari penelitian yang telah dilakukan. Teknik analisis data yaitu upaya yang dilakukan dengan jalan bekerja dengan data, mengelompokkan data, memilih - milihnya data yang dapat dijadikan kesatuan yang utuh yang dapat dianalisis. Sehingga dapat disimpulkan bahwa objek penelitian yang berupa novel Catatan Juang karya Fiersa Besari dengan menggunakan kajian stilistika akan membaca dengan memahami dan dapat mengelompokkan gaya bahasa yang digunakan dalam novel dan mampu mengelompokkan sesaui dengan jenis gaya bahasa, yang akan dipaparkan dalam hasil penelitian.

\section{HASIL DAN PEMBAHASAN}

\section{A. Gaya Bahasa Perbandingan}

Pradopo (2005) beranggapan bahwa gaya bahasa perbandingan adalah gaya bahasa yang menyamakan satu hal dengan yang lain dengan menggunakan kata - kata perbandingan, seperti:bak, bagai, dan semisal. Dari pendapat tersebut dapat disimpulkan bahwa gaya perbandingan adalah gaya bahasa yang memiliki maksud dan tujuan untuk membandingkan dua hal yang dianggap mirip. Gaya bahasa perbandingan memiliki jenis - jenis yaitu: metonomia, personifikasi, pleonasme, metafora, sinekdoke, alusi, simile, asosiasi, eufemisme, epitet, eponym, dan hipalase.

Tabel 01. Jumlah gaya bahasa perbandingan

\begin{tabular}{cc}
\hline Jenis gaya bahasa & $\begin{array}{c}\text { Jumlah gaya } \\
\text { bahasa }\end{array}$ \\
\hline Gaya bahasa hiperbola & 45 \\
Motanomia & 5 \\
Personifikasi & 20 \\
Perumpamaan & 35 \\
Pleonasme & 5 \\
Metafora & 3 \\
Simile & 3 \\
Asosiasi & 3 \\
Hipalase & 5 \\
\hline Total & $\mathbf{1 2 1}$ \\
\hline
\end{tabular}

Dari hasil analisis yang telah dilakukan ditemukan gaya bahasa perbandingan yaitu sebagai berikut:

1) Hiperbola

Gaya bahasa hiperbola adalah gaya bahasa yang mengandung suatu pertanyaan yang memiliki makna melebih - lebihkan suatu hal dan tidak sesaui dengan keadaan yang sebenarny (Keraf, 2004). Sehingga dapat disimpulakn bahwa gaya bahasa hiperbola adalah gaya bahasa yang memiliki makna yang tidak sesaui dengan keaadaan yang sebenarnya ataupun berlebihan.

Penggunaan gaya bahasa hiperbola sesaui dengan penelitian yang dilakukan oleh Ibrahim (2015) melakukan penelitian dan menghasilkan 
gaya bahasa yang digunakan dalam kumpulan novel Mimpi Bayang Jinggadana. Dalam penelitian yang telah dilakukan banyak menggunakan gaya bahasa hiperbola.

Dari penelitian yang telah dilakukan ditemukan 45 data yang menggunakan gaya bahasa hiperbola, diantaranya adalah sebagai berikut:

Data 1

"Suar berharap sakit di kepalanya segera hilang. Tekanan dari atasannya beberapa hari terakhir ini membuat kepalanya terasa ingin meledak. Namun, ia hanya bisa menunduk." (CJ,2)

Pada data (1) kutipan tersebut termasuk gaya bahasa hiperbola yang membuat pernyataan yang berlebihan yaitu pada kata kepalanya terasa ingin meledak. Pada kenyataannya kepadanya hanya pusing dan tidak mungkin bisa meledak.

Data 2

“... karena itu, Ibu dan Bapak panik tak karuan. Satu kampung dibuat geger.” (CJ, 16)

Pada data (2) Data kutipan novel termasuk dalam gaya bahasa hiperbola karena membuat pernyataan yang berlebihan yaitu pada kalimat satu kampung dibuat geger.

Data 3

“... namun, tatkala mengingat kondisi Bapak, Suar kembali mengubur ide gilanya”. (CJ, 51)

Pada data (3) data kutipan novel tersebut termasuk dalam gaya bahasa hiperbola yaitu menggunakan kata yang membesar - besarkan suatu hal yaitu mengenai mengubur ide gilanya. Hal ini seakan - akan memiliki ide yang bagus tetapi terpaksa harus dipendam terlebih dahulu.

Data 4

“lagi-lagi Suar merasa tertohok. Kepalanya seolah dipukul keras”. (CJ, 55)

Pada data (4) data kutipan novel tersebut termasuk dalam gaya bahasa yang menggunakan kata yang memiliki makna yang berlebihan yaitu pada kata tertohok dan dipukul keras.

Data 5

"Suar kembali bersin. Terkapar, tak berdaya”. (CJ,63)

Pada data (5) data kutipan novel tersebut termasuk dalam gaya bahasa yang menggunkan kata yang memiliki makna yang berlebihan dengan keaadaan yang sebenarnya yaitu pada kata terkapar tak berdaya.

2) Metanomia

Gaya bahasa metanomia adalah gaya bahasa yang menggunakan sebuah kata untuk menjelaskan ataupun untuk menyatakan sesuatu karean 
memiliki makna atau hubungan yang dekat (Keraf, 2004). Sehingga dapat disimpulkan bahwa gaya bahasa metanomia adalah gaya bahasa yang memberikan nama atau penanda yang sudah diketahui oleh banyak orang.

Penelitian mengenai gaya bahasa metanomia juga dilakukan oleh Khusnin (2012) menghasilkan sebenuh penemuan dari penelitian yaitu ditemukan jenis-jenis gaya bahasa dalam novel Ayat-Ayat Cinta karya Habiburrahman El Shirazy. Dari penelitian tersebut ditemukan gaya bahasa metanomia.

Dari penelitain yang telah dilakukan, ditemukan 5 gaya bahasa metanomia dalam novel Catatan Juang, yaitu antara lain:

Data 1

“... engkau membisikkan doa sambil mengelus perutmu, menungguku hadir, tak sabar mendengar tangis pertamaku, hampir meregang nyawa demi menghadirkanku ke bumi. Dan ketika aku lahir engkau tidak pernah mengeluh saat membersihkan kotoranku, tidak sama sekali." (CJ, 8)

Pada data (1) Kutipan data tersebut merupakan gaya bahasa perbandingan yang berjenis metanomia yaitu gaya bahasa yang mempergunakan sebuah kata untuk menyatakan suatu hal lain karena mempunyai pertalian yang sangat dekat. Pada data tersebut kata yang memiliki pertalian yang dekat adalah kata kehadiran.

3) Personifikasi

Gaya bahasa personifikasi adalah gaya bahasa yang yang menggunakan makna kiasan yang menggambarkan bahwa benda mati memiliki sifat seperti manusai (Keraf, 2004).

Dari penelitian yang telah dilakukan ditemukan gaya bahasa perbandingan jenis personifikais berjumlah 20 gaya bahasa personifikasi, antara lain sebagai berikut:

Data 1

"langit sedang menguning ketika Suar keluar dari kantor. Di kejauhan, tampak dua layangan berau mesra di angkasa”. (CJ, 85)

Pada data (1) kutipan novel tersebut menunjukkan bahwa terdapat kalimat yang merupakan gaya bahasa personifikasi yang menganggap bahwa benda hisup memiliki sifat - sifat kemanusiaan yaitu layang layang yang beradu mesra di angkasa.

Data 2

“... hujan makin deras menyambangi bumi”. (CJ,70)

Pada data (2) kutipan novel tersebut termasuk dalam gaya bahasa yang menggambarkan benda - benda mati memiliki sifat kemanusiaan yaitu pada kata hujan yang menyambangi bumi ini berarti bahwa hujan turun kebumi.

Data 3

"rintik mengetuk kaca jendela kamar Suar. Sudah dua jam berlalu, tetapi hujan belum juga reda”. (CJ, 68)

Pada data (3) kutipan novel tersebut termasuk dalam gaya bahasa personifikasi yang menunjukkan benda mati memiliki sifat kemanusiaan yaitu rintik hujan mengetuk jendela kamar Suar.

Data 4 
“... kubawa lamunanku pergi, kembali pada perpustakaan”. (CJ, 15)

Pada data (4) kutipan novel tersebut termasuk dalam gaya bahasa personifikasi yang menunjukkan benda mati memiliki sifat kemanusiaan yaitu pada kubawa lamunanku pergi.

\section{4) Perumpamaan}

Moeliono (1989) berpendapat bahwa perumpamaan adalah gaya bahasa perbandingan yang membandingkan dua hal yang berbada namun dianggap memiliki kesamaan. Gaya bahasa perumpamaandapat disimpulka yaitu perbandingan dua hal yang hakikatnya berlainan dan yang sengaja dianggap sama. Terdapat kata laksana, ibarat, dan sebagainya yang dijadikan sebagai penghubung kata yang diperbandingkan.

Dari hasil analisis yang telah dilakukan gaya bahasa dalam novel Catatan Juang ditemukan 35 gaya bahasa perumpamaan dalam novel, diantaranya adalah sebagai berikut:

Data 1

“... lalu ibu akan menyeret aku dan adikku pulang, memaksa kami mandi, dan membedaki wajah kami sangat terlihat seputih aktor pantomim." (CJ, 14)

Pada data (1) kutipan novel tersebut termasuk dalam gaya abhasa perumpamaan yang menunnjukkan dua hal yang berlainan namun dianggap sama yaitu wajah yang seperti aktor pantomin.

Data 2

“... perempuan paruh baya bertubuh gempal itu memang senang sekali marah - marah pada mereka yang dianggapnya merugikan perusahaan”. (CJ, 21)

Pada data (2) kutipan data tersebut termasuk dalam gaya bahasa perumpamaan karena data tersebut menunjukka dua hal yang berbeda dianggap sama yaitu pada kalimat perempuan paruh baya bertumbuh gempal.

Data 3

"bukankah Ibu tidak pernah meninta untuk memikul beban ini sendirian dan bertingkah bak superhero?". (CJ, 55)

Pada data (3) kutipan novel tersebut menunjukkan bahwa terdapat gaya bahasa perumpamaan yang membandingkan dua hal yang berbeda dianggap sama yaitu dengan adanya kata bak seperhero yang menganggap bahwa Suar mirip superhero.

\section{Data 4}

“... setelah Ibu tiada, perekat kami seolah hilang. Suasana rumah tidak lagi sama. Kini menjadi semavam terminal di mana kami cuma singgah sebentar sebelum kembali pergi kepada dunia kami masing - masing”. (CJ, 106) 
Pada data (4) kutipan novel tersebut termasuk dalam gaya bahasa yang mengandung perbandingan dua hal yang berbeda namun dianggap memiliki makna yang berbeda, yaitu pada kata terminal.

5) Pleonasme

Gaya bahasa pleonasme adalah gaya bahasa yang menggunakan acuhan yang menggunakan kata - kata yang lebih kompleks untuk menjelaskan suatu hal dan jika salah satu kata dihilangkan tidak mengubah makna kalimat tersebut (Keraf, 2004). Gaya bahasa pleonasme dapat disimpulkan menggunakan dua kata yang sama arti sekaligus, tetapi sebenarnya tidak perlu, baik untuk penegas arti maupun hanya sebagai gaya.

Dari penelitian yang telah dilakukan ditemukan gaya bahasa pleonasme sejumlah 5 gaya bahasa dalam novel Catatan Juang, diantaranya sebagai berikut:

Data 1

“... Suar duduk di bagian paling belakang mobil angkutan umum, berimpitan dengan beberapa manusia yang baru saja menyelesaikan rutinitas harian mereka. Gadis itu menyandarkan kepada di jendela, merasakan getaran mesin mobil tua yang membawanya pulang dari kantor, meninggalkan setumpuk pekerjaan yang belum juga ia bereskan." (CJ,2)

Pada data (1) menunjukkan bahwa gaya bahasa pleonasme adalah gaya bahasa semacam acuan yang menggunakan kata - kata lebih banyak daripada yang diperlukan, untuk menyatakan satu gagasan atau pikiran. Dalam kutipan tersebut menjelaskan kegiatan suar yang mendetail atau menggunakan kata - kata yang berlebihan dan memiliki makna yang sama jika ada kata yang dihilangkan.

Data 2

“...seorang laki - laki yang duduk di sebelahnya berdiri. Lelaki itu cukup menyulitkan tatkala hendak turun dari mobil. Tubuhnya yang tinggi besar membuat suar mesti merapatkan diri pada kaca." (CJ,2)

Pada data (2) kutipan tersebut termasuk gaya bahasa pleonasme yang memberikan penjelasan secara lebih banyak yaitu tentang seorang laki - laki yang memiliki tubuh tinggi besar.

Data 3

“... maka dari itu, ia harus bergegas berangkat dan membuktikan dirinya mampu menjadi pegawai teladan, seolah - olah ia membenarkan bahwa manusia yang berkerja lebih pagi, pasti mendapatkan rezeki yang lebih banyak". (CJ, 11-12)

Pada data (3) kutipan novel tersebut termasuk dalam gaya bahasa pleonasme yang menberikan penjelasan yang berlebihan yang memiliki arti yang sama jika dipersingkat lagi.

6) Metafora 
Keraf (2004: 139) berpendapat bahwa metafora adalah gaya abhasa yang menggunakan analogi untuk membandingkan dua anlogi secara langsung.

Dari hasil penelitian yang telah dilakukan dtemukan 3 gaya bahasa metafora diantaranya adalah sebagai berikut:

Data 1

“... ketahuilah, mantan pacar adalah guru kehidupan. Melalui rasa sakit ia mendewasakan kita”. (CJ, 40)

Pada data (1) kutipan novel tersebut termasuk dalam gaya bahasa perbandingan yang menunjukkan membandingkan dua hal yang berbeda dalam waktu yang singkat, yaitu pada kata mantan pacar menjadi guru kehidupan karena hal tersebut adalah dua hal yang berbeda.

7) Simile

Simile adalah gaya bahasa yang membandingkan dua hal yang bersifat eksplisit atau secara langsung untuk menyatakan hal lain (Keraf, 2004). Sementara itu simile atau perumpamaan dapat diartikan suatu majas membandingkan dua hal/benda dengan menggunakan kata penghubung.

Dari hasil analisis gaya bahasa yang telah dilakukan ditemukan 3 gaya bahasa yang menggunakan gaya bahasa simile, diantaranya adalah sebagai berikut:

Data 1

“...Sementara ingar-bingar obrolan segerombolan ibu-ibu yang membicarakan gosip terkini, juga sepasang anak remaja yang memadu asmara." (CJ,2)

Pada data (1) menunjukkan bahwa gaya bahasa simile adalah gaya bahasa yang bersifat eksplisit yang langsung menyatakan sesuatu dengan hal yang lain. Dalam kutipan tersebut menyatakan bahwa segerombolan ibu - ibu yang ramai dengan membicarakan gosip, sedangkan anak muda sedang berpacaran.

Data 2

“... raut wajah mereka berubah menjadi senyum lebar. Mereka geleng geleng kepala”. (CJ, 13)

Pada data (2) data kutipan tersebut termasuk dalam gaya bahasa simili yang membandingkan sesuatu hal secara langsung, yaitu membandingkan raut wajah yang berubah menjadi senyum lebar.

8) Asosiasi

Asosiasi adalah gaya bahasa perbandingan yang membandingkan sesatu yang berlainan dengan suatu keadaan yang dilukiskan (Maulana, 2008). Pendapat tersebut menyiratkan bahwa asosiasi adalah gaya bahasa yang berusaha membandingkan sesuatu dengan hal lain yang sesuai dengan keadaan yang sebenarnya.

Dari hasil analisis yang telah dilakukan ditemukan gaya bahasa asoiasi yaitu berjumlah 3 data diantaranya adalah sebagai berikut:

Data 1 “...Sesudah menaruh sandal dan sepatu sebagai tanda batas, kami berlari ke sana kemari dengan tawa riang menghiasi wajah kami yang berkeringat." (CJ, 14) 
Pada data (1) kutipan tersebut termasuk dalam gaya bahasa perbandingan asosiasi yang menunjukkan perbandingan yang bersifat memperbandingkan sesuatu dengan keaadan lain sesaui dengan keaadan yang dilukiskan. Dalam data tersebut kata yang menunjukkan gaya bahasa asosiasi adalah kami berlari kesana kemari dengan tawa riang menghiasi wajah kami.

9) Hipalase

Hipalase adalah gaya bahasa yang menggunakan sebuah kata tertentu untuk menjelaskan sesuatu yang seharusnya digunakan untuk menerangkan makna lain (Keraf, 2004). Maksud pendapat di atas adalah hipalase merupakan gaya bahasa yang menerangkan sebuah kata tetapi sebenarnya kata tersebut untuk menjelaskan kata yang lain

Dari hasil analisis yang telah dilakukan ditemukan 5 gaya bahasa yang merupakan gaya bahasa hipalase, diantaranya adalah sebagai berikut:

Data 1

“...ayahnya pernah berpesan, yang penting kamu harus sekolah yang tinggi, biar Bapak dan Ibu bangga". (CJ, 45)

Pada data (1) kutipan novel tersebut menggunkana gaya bahasa yang memperggnakan kata tertentu untuk menerangkan sebuah makna yaitu kata sekolah yang tingg ini bukan sekolah yang bergendung tinggi melainkan sekolah samapi dengan memiliki gelar yang tinggi.

Data 2

"...memiliki kamera sendiri membuat Suar terus menghasilkan film - film pendek bak orang gila”. (CJ, 46)

Pada data (1) kutipan novel tersebut termasuk dalam gaya bahasa yang mempergunakan kata tertentu untuk menerangkan sebuah kata yang seharusnya dikenakan pada sebuah kata yang seharusnya dikenakan pada sebuah kata lain, data tersebut menggunakan kata bak orang gila yang gila bukan orangnya tetapi karya yang telah dihaslkan oleh Suar. 


\section{B. Relevansi Hasil Penelitian sebagai Baham Ajar Sastra SMA}

Pembelajaran sastra selama ini merupakan suatu bagian dari pembelajaran bahasa yang disatukan dengan mata pelajaran Bahasa Indonesia (Sufanti, 2016). Menurut Rohman (2012) pengajaran sastra juga merupakan interaksional yang membagun pengetahuan tentang sastra. Menurut Lazar (dalam Al-Ma'ruf, 2007) menjelaskan bahwa fungsi pembelajran sastra adalah sebagai berikut:

1) Sastra berfungsi sebagai alat untuk merangsang siswa dalam mengembangkan pengalaman, kemampuan, dan pendapatnya.

2) Sastra sebagai alat untuk membantu siswa dalam mengembangkan kemampuan intelektual dan emosional dalam mempelajari bahasa.

3) Sastra sebagai alat simulasi dalam pemeroleh kemampuan berbicara dan berbahasa.

Pada suatu pembelajaran tidak akan pernah terlepas dari bahan ajar pembelajaran. Hasil penelitian yang telah dilakukan yaitu berupa unsur pembangun novel dan analisis gaya bahasa yang mampu digunakan sebagai bahan ajar dalam proses pembelajaran. Hal ini yang mendasari penelitian untuk dijadikan alternatif sebagai bahan ajar sastra SMA.

1) Kelayakan Novel sebagai Bahan Ajar

Dalam pemilihan bahan ajar, terdapat beberapa aspek yang perlu diperhatikan. Menurut Rahmanto (2005) memaparkan bahwa memilih bahan pengajaran sastra harus mempertimbangkah hal- hal sebagai berikut:

a. Aspek Bahasa

Aspek kebahasaan dalam sastra tidak hanya ditentukan oleh masalah - masalah yang dibahas dalam suatu novel, tetapi juga faktor - faktor lain yang meliputi aspek kebahasaan yaitu waktu penulosan karya itu, dan kelompok pembaca yang ingin dijangkau pengarang. Pemilihan bahan ajar yang baik harus disesauikan dengan wawasan yang ilmiah yaitu dari segi memperhatikan kosa- kata yang baru, memperhatikan segi ketatabahasaan dan sebagainya (Rahmanto, 2005). Dalam novel yang berjudul Catatan Juang cocok digunakan sabagai bahan ajar karena aspek bahasa yang digunakan mudah untuk dipahami siswa, serta dalam novel memiliki cerita yang sangat pas untuk anak SMA karena menceritakan tentang seirang gadis yang keluar dari zona nyaman untuk mengejar citacita yang diinginkan, dan memiliki aspek kebahasaan yang sesuai dengan anak SMA.

b. Aspek psikologi

Aspek psikologi berarti ilmu jiwa. Aspek psikologi harus diperhatikan dalam pemilihan bahan ajar. Menurut Rahmanto (2005), tahap - tahap perkembangan psikologis sangat berpengaruh terhadap daya ingat siswa. Pada usia remaja siswa sudah mengetahui perilaku yang baik dan benar serta sudah mampu membedakan antara yang benar dan yang salah. Sehingga dalam pemilihan bahan ajar harus biasa memahami esensi dari bahan ajar tersebut. novel Catatan Juang memiliki aspek yang lengkap untuk perkembangan psikologi siswa.

c. Aspek Latar Budaya

Aspek latar budaya sangat berpeangrun dalam penyusunan bahan ajar, karena siswa akan tertarik dengan latar budaya yang sesaui dengan kehidupan mereak, sehingga berlantar belakang orang yang biasa akan tetapi mampu menjadi orang sukses sangat digemari oleh siswa. Hal 
tersebut sesaui dengan alur cerita yang ada pada novel Catatan Juang yang meliki latar belakdang yang sederhana namum memiliki aspek yang luar biasa.

2) Relevansi Hasil Penelitian dengan Kompetensi Dasar

Hasil penelitian yang telah dilakukan adalah berupa unsur intrinsik novel dan gaya bahasa yang digunakan dalm novel akan direlevansikan terhadap KI yang terdapat pada pembelajaran Bahasa Indonesia yang terdiri dari kompetensi spiritual, kompetensi sosial, kometensi pengetahuan dan kompetensi keterampilan. Hasil penelitian tersebut dapat direlevansikan terhadap KI pengetahuan dalam pembelajaran Bahasa Indonesia. Hasil penelitian yang berupa unsur pembangun atau unsur intrinsik novel dan penggunaan gaya bahasa dalam novel terdapat kesesuaian dengan kompetensi pengetahuan dan terdapat kesesuain juga dengan KD. 3.9 yaitu menganalisis isi dan kebahasaan novel. Hasil dari unsur intrinsik berupa tema, alur, tokoh dan penokohan, serta latar. Serta gaya bahasa dalam novel juga biasa digunakan dalam KD. 3. 9 dalam kebahasaan novel.

\section{PENUTUP}

Dari penelitian yang telah dilakukan tentang gaya bahasa dalam novel Catatan Juang karya Fiersa Besari yaitu berjumlah 121. Gaya bahasa perbandingan yang sring digunakan oleh Fiersa Besari adalah gaya bahasa hiperbola, karena penulis banyak menggunakan pernyataan yang memiliki arti yang melebih lebihkan makna yang sebenarnya. Gaya bahasa dalam novel ini menarik untuk dianalisis karena penulis menggunaan kata kalimat yang sederhana namum memiliki makna yang mudah dipahami. Serta dalam novel menggunakan bahasa yang pas untuk anak remaja terutama SMA sehingga pas untuk digunakan sebagai bahan ajar di SMA. Relevansi hasil penelitian yang telah dilakukan memiliki relevansi sebagai bahan ajar, karena memiliki kelayakan dari aspek bahasa, psikologi, dan latar budaya sehingga novel dapat dijadikan bahan ajar sastra karena memiliki bahasa yang mudah dipahami dan memiliki makna yang baik untuk anak SMA. Hasil penelitian juga direlevansikan dalam KD 3.9 yaitu menganalisis isi dan kebahasaan novel. Hasil dari unsur intrinsik berupa tema, alur, tokoh dan penokohan, serta latar. Serta gaya bahasa dalam novel juga biasa digunakan dalam KD. 3. 9 dalam kebahasaan novel. 


\section{DAFTAR PUSTAKA}

Aminuddin. 1995. Stilistika Pengantar Memahami Bahasa dalam Karya Sastra. Semarang: IKIP Semarang Press.

Faricha, Nury Ziyadatu. 2015." Penggunaan Diksi dan Gaya Bahasa Pada Novel "Daun Yang Jatuh Tak Pernah Membenci Angin" Karya Tere Liye". Nosi. 2 (9). Hal:146152.

Khair, U., \& Misnawati, M. (2022). Indonesian language teaching in elementary school: Cooperative learning model explicit type instructions chronological technique of events on narrative writing skills from interview texts. Linguistics and Culture Review, 6, 172-184.

Ibrahim, Soleh. 2015. "Analisis Gaya Bahasa dalam Kumpulan Novel Mimpi Bayang Jingga Karya Sanie B. Kuncoro”. Jurnal Sasindo Umpan. 3(3). Hal: 35-57.

Jabrohim. 2001. Metodologi Penelitian Sastra. Yogyakarta: Hanindita Graha Widia.

Keraf, gorys. 2004. Diksi dan Gaya Bahasa. Jakarta: Gramedia Pustaka Utama.

Khusnin, Mukhamad. 2012." Gaya Bahasa Novel Ayat-Ayat Cinta Karya Habiburrahman El Shirazy dan Implementasinya Terhadap Pengajaran Sastra Di SMA”. Seloka: Jurnal Pendidikan Bahasa dan Sastra Indonesia. 1 (1). Hal: 45-53.

Misnawati, M., Linarto, L., Poerwadi, P., Nurachmana, A., Purwaka, A., Cuesdeyeni, P \& Asi, Y. E. (2021). Sexuality Comparison in Novel Eleven Minutes with Tuhan Izinkanlah Aku Menjadi Pelacur! Memoar Luka Seorang Muslimah. AKSIS: Jurnal Pendidikan Bahasa dan Sastra Indonesia, 5 (1), 1-14.

Misnawati, M. P., \& Anwarsani, S. P. (2000). Teori Stuktural Levi-Strauss dan Interpretatif Simbolik untuk Penelitian Sastra Lisan. GUEPEDIA.

Moeliono, Anton. M. 1989. Kembara Bahasa. Jakarta: PT Gramedia.

Moleong. 2010. Metodologi Penelitian Kualitatif. Bandung: PT Remaja Rosdakarya.

Nababan, V. D., Diman, P., \& Cuesdeyeni, P. (2021). Gaya Bahasa Perbandingan dalam Novel Garis Waktu Karya Fiersa Besari. ENGGANG: Jurnal Pendidikan, Bahasa, Sastra, Seni, dan Budaya, 2(1), 67-78.

Perdana, I., \& Misnawati, M. P. (2019). Cinta dan Bangga Berbahasa Indonesia di Perguruan Tinggi. SPASI MEDIA.

Pradopo, Rachmad Djoko. 2005. Beberapa Teori Sastra, Metode, Kritik, dan Penerapannya. Yogyakarta: Pustaka Pelajar.

Raharjo, Yusuf Muflikh, dkk. 2017. "Pendidikan Karakter dalam Novel Nun pada Sebuah Cermin Karya Afifah Afra Serta Relevansinya dengan Materi Ajar di Sma". Jurnal Pendidikan Indonesia. 6(1). Hal: 16-26.

Sayuti, Suminto. A. 2000. Berkenalan dengan Prosa Fiksi. Yogyakarta: Gama 
Enggang: Jurnal Pendidikan, Bahasa, Sastra, Seni, dan Budaya

Sudjiman, Panuti. 1993. Bunga Rampai Stilistika. Jakarta: Grafiti.

Sunanda, Adyana dan Zainal Arifin. 2020. Teori Sastra. Surakarta: Muhammadiyah University Press.

Susilowati, Emy. 2016. "Gaya Bahasa dalam Novel Pesantren Impian Karya Asma Nadia”. Jurbal Bastra (Bahasa dan Sastra). 1(2). Hal: 1-19. 